\title{
PASSIVE HAEMAGGLUTINATION TEST FOR HUMAN NEUROCYSTICERCOSIS IMMUNODIAGNOSIS. I. STANDARDIZATION AND EVALUATION OF THE PASSIVE HAEMAGGLUTINATION TEST. FOR THE DETECTION OF ANTI-Cysticercus cellulosae ANTIBODIES.
}

Mirthes UEDA (1), Eide Dias CAMARgo (1), Adelaide José VAZ (1), Ana Maria Carvalho de SoUZA (1), Regina Maria Figueiredo (1) \& Marcos Vinicius da SILVA (2)

\begin{abstract}
S U M M A R Y
A passive haemagglutination test (PHA) for human neurocysticercosis was standardized and evaluated for the detection of specific antibodies to Cysticercus celluIosae in cerebrospinal fluid (CSF). For the assay, formaldehyde-treated group $O$ Rh-human red cells coated with the cysticerci crude total saline extract (TS) antigen were employed. A total of $115 \mathrm{CSF}$ samples from patients with neurocysticercosis was analysed, of these 94 presented reactivity, corresponding to $81.7 \%$ sensitivity, in which confidence limit of $95 \%$ probability $\left(\mathrm{CL}_{95 \%}\right)$ ranged from $74.5 \%$ to $88.9 \%$. Eighty-nine CSF samples derived from individuals of control group presented as nonreactive in $94.4 \%\left(\mathbf{C L}_{95}\right.$, from $89.6 \%$ to $\left.99.2 \%\right)$. The positive and negative predic tive values were $1.4 \%$ and $99.9 \%$, respectively, considering the mean rate of that this assay provide a rapid, highly reproducible, and moderately sensitive mean of detecting specific antibodies in CSF samples.
\end{abstract}

KEY WORDS: Neurocysticercosis; Passive haemagglutination test; Cerebros pinal fluid.

\section{N T R O D U C T I O N}

Human cysticercosis, a disease caused by Cysticercus cellulosae, the Taenia solium larva, is a serious public health problem, mainly in de veloping countries ${ }^{5}$. The Cysticercus cellulosae may situate in some human body structures or organs, however the most serlous and frequent form is central nervous system localization ${ }^{15,17}$.

A heterogeneity of clinical manifestations occurs in neurocysticercosis. These may be asymptomatic or symptomatic including con- vulsion accompained by intracranial hypertension or not and, occasionally, it is necessary to remove the parasite by surgery. The laboratorial diagnosis assaying cerebrospinal fluid (CSF) for specific antibody detection, may institute adequate treatment and thus, prevent progression to serious forms.

A passive haemagglutination test (PHA) for Cysticercus cellulosae antibody for neurocysticercosis diagnosis has been employed by several

(1) Seçào de Sorologia do Instituto Adolfo Lutz - São Paulo, S.P

(2) Seção de Sorologia do Instituto Adolfo Lutz -- São Paulo e do Hospital Emílio Ribas - São Paulo, S.P.

Correspondence address: Instituto Adolfo Lutz; Av. Dr. Arnaldo, 351 - 10, andar; 01246 - Sào Paulo, S.P. - Brasil 
UEDA, M.; CAMARGO, E D.; VAZ A. J.; SOUZA, A. M. C. de; BENELLI, R M. F. \& SILVA, M. V. da - Passive haemagglutination test for human neurocysticercosis immunodiagnosis. I. Standardization and evaluation of the passive haemagglutination test for the detection of anti-Cysticercus cellulosae antibodies.

Rev. Inst. Med. trop. Săo Paulo, 30 (1): 51-56, 1988.

authors ${ }^{1,8}, 10,12,13$, using different antigens. BIA GI et al. ${ }^{1}$ described a PHA test employing aceto ne-treated and phosphate-buffered saline (PBS) extracted cysticerci antigen. PROCTOR et al. ${ }^{13}$ sensitized erythrocytes with delipidized cysticerci saline extract antigen. POWELL et al. ${ }^{12}$ used as antigen the total crude extract from Cysticercus cellulosae. MARTINEZ-CAIRO et al. ${ }^{8}$ described a PHA test utilizing erythrocytes with membrane and scolex antigens from cysticerci, and considering that the low concentration of immunoglobulin in CSF should be a limitation for detecting specific antibodies, they employed amonium sulphate five-fold concentrated sam. ples. NASCIMENTO \& MAYRINK ${ }^{10}$ evaluated the PHA test in sera, using different antigens extracted from cysticerci. These authors observed that the scolex antigen was more specific than total crude antigen and those extrated from cysticerci vesicular fluid and membrane. More recently, $\cos \mathrm{TA}^{3}$ reported a $100 \%$ positivity with cysticerci total saline extract antigen, in enzyme immunoassay (ELISA).

As this antigen has not been tried before in any other serological tests, further assessment of this Cysticercus cellulosae total saline ex tract antigen for detecting antibody in CSF from patients with neurocysticercosis was performed by PHA test.

\section{MATERIAL AND METHODS}

ANTIGEN - Cysticerci obtained from naturally infected pig muscle and viscera were exhaustively washed in saline solution $(0.15 \mathrm{M}$ $\mathrm{NaCl}$ ). The crude total saline extract antigen (TS) was obtained as described by CosTA $(1983)^{3}$, with some modifications. Briefly, about 200 cysticerci were homogenized in $10 \mathrm{ml}$ of distilled water in tissue grinder Potter (Scientific Glass Apparatus Inc. USA), and disrupted by sonication (Thorton-Inpec Eletrônica, Brasil) at four periods of 60 seconds $-20 \mathrm{Khz}-1 \mathrm{~mA}$, in an ice bath. After adding $10 \mathrm{ml}$ of $0.3 \mathrm{M} \mathrm{NaCl}$ solution for isotonization, the mixture was sonicated again and left overnight at $4^{\circ} \mathrm{C}$ with gentle stirring. After centrifugation at $6,500 \mathrm{x} \mathrm{g}$ for 30 minutes at $4^{\circ} \mathrm{C}$, the supernatant was centrifuged again at $9,000 \times \mathrm{g}$ for 30 minutes a $4^{\circ} \mathrm{C}$. The supernatant resulting from this last centrifugation, which corresponds to TS antigen, was frozen in one mi-aliquots at $-70^{\circ} \mathrm{C}$, and then lyophilized (Edwards do Brasil, Brazil), and stored at $4^{\circ} \mathrm{C}$ until use. The antigen extract protein and polysaccharide contents were determined by BRADFORD ${ }^{2}$ method and antrone test ${ }^{16}$, respectively.

To determine the optimum concentration of antigen to be employed for red cells coating, the block titration was carried out, assaying positive standard CSF obtained from patient with neurocysticercosis and negative standard CSF from healthy individual.

CEREBROSPINAL FLUID (CSF) - It were assayed 115 CSF samples from patients with neurocysticercosis confirmed by epidemiological, clinical and laboratorial data. The control group was consisted of 57 CSF samples from neurological patients with diagnosis other than cysticercosis (as meningitis, neurosyphilis, tumors, vascular accidents, hydrocephalus, coma), and 32 samples from apparently healthy individuals.

PASSIVE HAEMAGGLUTINATION TEST (PHA) - Formaldehyde-treated group O Rh-human erythrocytes were sensitized with TS antigen as previously described by HOSHINO-SHIMIZU et al. ${ }^{6}$. Briefly, a $0.5 \%$ cell suspension was washed three times in 20 volumes of saline solution, and after last centrifugation the cell pellet was resuspended in an original volume with saline solution. Equal volume of a $1 / 15,000$ dilution of tannic acid diluted in saline solution was ad. ded to the suspension. Tanning was carried out for 10 minutes at $56^{\circ} \mathrm{C}$ in a water-bath, with frequent agitation. After tanning, the cells were washed three times by centrifugation at $800 \mathrm{x} \mathrm{g}$ for 10 minutes. Then, they were resuspended to the original volume with solution of TS antigen at the optimal dilution in $0.15 \mathrm{M}$ phosphate buffered saline solution (PBS) at $\mathrm{pH} 6.4$, and incubated for 50 minutes at $37^{\circ} \mathrm{C}$, under gentle shaking. After coating, equal volume of a $0.1 \%(\mathrm{v} / \mathrm{v})$ glutaraldehyde solution, diluted in saline solution, was added and the suspension was incubated for 20 minutes again at $37^{\circ} \mathrm{C}$, in water-bath. The coated cells were washed three times in PBS and they were made up to one to third of original volume in stabilizing solution ${ }^{6}$, and lyophilized. For use, the cells were reconstituted to original volume with distilled water; the final concen- 
UEDA, M.; CAMARGO, E. D.; VAZ, A. J.; SOUZA, A. M. C. de; BENELLI, R. M. F. \& SILVA, M. V. da - Passive haemagglutination test for human neurocysticercosis immunodiagnosis. I. Standardization and evaluation of the passive haemagglutination test for the detection of anti-Cysticercus cellulosae antibodies. Rev. Inst. Med. trop. Sá Paulo, 30 (1): $51-56,1988$

tration of cells was $0.5 \%$. Following the same procedure, the control cells were prepared replacing antigen by $\mathrm{pH}$ 6.4 PBS, during antigen coating step.

PHA test was carried out in the polystyrene V-shaped 96-well microtitration plates (Inlab, Brazil) by adding 25 microlitres volumes of a $0.5 \%$ cell suspension to a 25 microlitres of neat and a twofold series dilution of $\mathrm{CSF}$ in $\mathrm{pH} 6.4$ PBS. Each CSF sample dilution was simultaneously tested with uncoated cells. The plates were shaken for 30 seconds in plate shaker (Titertek, Flow Laboratories, USA), and kept in a wet chamber at room temperature. The titration end points were determined after 30 minutes incubation, when the positive and negative controls showed maximum contrast.

STATISTICAL ANALYSIS - The sensitivity, specificity, positive and negative predictive values rates and efficiency of the test were determined according to GALEN \& GAMBINO ${ }^{4}$, on the basis of considering $0.1 \%$ the prevalence of neurocysticercosis as calculated by SCHENONE et al. ${ }^{15}$.

\section{RESULTS}

Table 1 shows the determination of TS antigen protein and polysaccharide contents.
According to the results obtained in antigen block titration, the concentration of $60 \mu \mathrm{g} / \mathrm{ml}$ was selected for coating the erythrocytes.

Table II shows the PHA test results assayed in the total of $204 \mathrm{CSF}$ samples including patients with neurocysticercosis and from indivi duals of control group.

Of the $115 \mathrm{CSF}$ samples from neurocysticercosis patient 94 presented reactivity, providing $81.7 \%$ sensitivity with the confidence limit of 95\% probability $\left(\mathrm{CL}_{95 \%}\right.$ ) ranging from $74.5 \%$ to $88.9 \%$.

The assay performed in 89 CSF samples from individuals of control group demonstrates non reactivity in $94.4 \%$ at $\mathrm{CL}_{95 \%}$ ranging from $89.6 \%$ to $99.2 \%$

The positive and negative predictive values and the test efficiency are $1.4 \%, 99.9 \%$ and $94.4 \%$, respectively, when these rates are calculated under the estimation that, the mean rate of preva lence of human neurocysticercosis in Latin Ame rica is 100 cases per 100,000 inhabitants, that is to say 1 per 100 .

\section{DISCUSSION}

The PHA test for cysticercosis has been considered as the more sensitive technique than pre-

\section{TABLE I}

\section{Proteins and polysaccharides concentrations in Cysticercus cellulosoe total saline antigenic extract.}

\begin{tabular}{ccc}
\hline $\begin{array}{c}\text { ANTIGENIC } \\
\text { EXTRACT }\end{array}$ & $\begin{array}{c}\text { PROTEIN } \\
\mathbf{m g} / \mathrm{ml}\end{array}$ & $\begin{array}{c}\text { POLYSACCHARIDES } \\
\mathbf{m g} / \mathbf{m l}\end{array}$ \\
\hline $\begin{array}{c}\text { TOTAL SALINE } \\
(10 \mathrm{cysticerci} / \mathrm{m})\end{array}$ & 6.1 & 5.2 \\
\hline
\end{tabular}




\section{TABLE I I}

\section{Frequency of antibody titres by means of passive haemagglutination test in CSF samples according to three differents group of individuals.}

\begin{tabular}{|c|c|c|c|c|c|c|c|c|c|c|c|c|c|c|}
\hline \multirow[b]{2}{*}{ GROUP } & \multicolumn{13}{|c|}{ TITRES } & \multirow[b]{2}{*}{ TOTAL } \\
\hline & N R & 1 & 2 & 4 & 8 & 16 & 32 & 64 & 128 & 256 & 512 & 1024 & 2048 & \\
\hline a & 21 & 8 & 22 & 15 & 22 & 3 & 13 & 5 & 4 & 1 & - & - & 1 & 115 \\
\hline b & 54 & 1 & 2 & - & - & - & - & - & - & - & - & - & - & 57 \\
\hline c & 30 & 2 & - & - & - & - & - & - & - & - & - & - & - & 32 \\
\hline
\end{tabular}

NR $=$ nonreactive

GROUP $\mathbf{a}=$ neurocysticercotic patients

$\mathbf{b}=$ patients with neurological clinical sintomatology other than cysticercosis

c = presumably healthy individuals

cipitation and complement fixation test; however, cross-reactivity is observed, when the method is performed in sera, mainly from individuals with non-related intestinal parasites, highly frequent in our environment ${ }^{1,7,13,14}$

The neurocysticercosis is surely the most frequent and serious form of human cysticercosis, and considering that specific immunoglobulins production is confined to the structures surrounding the parasite, it seems that CSF is the best specimen for immunodiagnostic tests, in relation to serum with its complex interfering components $^{9,11}$

Following this notion, a PHA test has been carried out for immunological diagnosis of neu rocysticercosis employing CSF as clinical specimen. The antigen employed in this test displays as of the easy preparing and satisfactory yield. The TS antigen, the coated and uncoated erythrocytes stored after lyophilization kept stable at $4^{\circ} \mathrm{C}$ for more than one year (data not shown).

It is observed that the positivity of $81.7 \%$ obtained for CSF samples from neurocysticercosis patients is satisfactory, since it is higher than those achieved by BIAGI et al. ${ }^{1}(10 \%)$ and MARTINEZ-CAIRO et al. ${ }^{8}(68 \%)$. The maximum positivity $(100 \%)$ was obtained by $\operatorname{COSTA}^{3}$ in 48 CSF samples employing vesicular fluid as antigenic preparation. However, this antigen is of limited use by its low yielding and will increase the reagent cost for the screening of infected individuals in endemic areas.

The specificity of the standardized haemagglutination test was verified to be high $(94.4 \%)$, and this is consistent with that was expected for PHA technique. With respect to the five CSF false positive results, two of them derived from patients with presumably viral lymphocytic meningitis, one from patient with hydrocephalus, and two from presumably healthy individuals without any clinical manifestation suggestive of disease.

The low positive predictive value demonstrated in this study resulted from the accounting the low prevalence of disease, according to few available data ${ }^{15}$. In accordance with GALEN \& GAMBINO $^{4}$, it is desirable a more sensitive test than specific one, when the disease is serious, its treatment is uncertain, and its diagnosis has public health value. 
UEDA. M.: CAMARGO, E. D.; VAZ, A. J .; SOUZA. A. M. C. de; BENELLI, R. M. F. \& SILVA, M. V da-Passive haemagglutination test for human neurocysticercosis immunodiagnosis. I. Standardization and evaluation of the passive haemagglutination test for the detection of anti Cysticercus cellulosae antibodies. Rev. Inst. Med. trop. São Paulo, 30 (1): 51.56 .1988$.

The sensitivity of PHA test in derecting spe cific antibodies in CSF samples, makes it 11seful for neurocysticercosis diagnosis, mainly in nega tive cases by means of other less sensitive serological tests routinely used. Also, this test demonstrates to be easy to perform and provides highly reproducible results.

\section{RESUMO}

Reação de hemaglutinação passiva para o imunodiagnóstico da neurocisticercose humana. I. Padronizaçáo e avaliação do teste de hemaglu. tinação passiva para a detecçāo de anticorpos anti-Cysticercus cellulosae.

Foi padronizada e avaliada a reaçāo de he maglutinação passiva (RHA) para pesquisa de anticorpos específicos, anti-Cysticercus cellulo. sae, no líquido cefalorraquiano (LCR). Foram utilizadas hemácias humanas O Rh-formolizadas e sensibilizadas com extrato antigênico salino total de cisticercos, ainda pouco estudado. De 115 amostras estudadas de LCR de pacientes com neurocisticercose, 94 foram reagentes, resultando em $81,7 \%$ de sensibilidade, com intervalo de confiança de $95 \%$ de probabilidade ( $\mathrm{IC}_{95 \%}$ ) abrangendo de $74,5 \%$ e $88,9 \%$. Também foram ensaiadas 89 amostras de LCR de indivíduos do grupo controle, sendo tão reagentes em $94,4 \%$, com $\mathrm{IC}_{95 \%}$, de $89,6 \%$ a $99,2 \%$. Os valores preditivos positivo e negativo obtidos para a RHA foram, respectivamente, de $1,4 \%$ e $99,9 \%$, considerando a prevalência média de neurocisticercose na América Latina de $0,1 \%$. Os resultados indicam que a RHA como um método simples, altamente reprodutível e moderadamente sensivel para a detecçảo de anticorpos específicos no LCR, porém apropriados para a triagem de infectados.

\section{ACKNOWLEDGEMENTS}

We wish to thank Dr. Aluízio de Barros Barreto Machado and Dr. Gilberto Eduardo Bassi of the Laboratório Central do Hospital das Clínicas da Faculdade de Medicina da Universidade de São Paulo for providing us with CSF samples and patients clinical data.

\section{REFERENCIAS BIBLIOGRAFICAS}

1. BIAGI. F. F.: NAVARRETE. F.: PIÑA, A. P : SANTIAGO A. M. \& TAPIA, L. - Estudio de tres reacciones serológicas en el diagnóstico de la cisticercosis. Rev. méd. Hosp. gen. (Méx.), 25: 501-508, 1961

2. BRADFORD, M. M. - A rapid and sensitive method for the quantitation of microgram quantities of protein utili. zing the principle of protein dye binding. Analyt. Biochem., 72: 248-254, 1976 .

3. COSTA, J. M. - Teste imunoenzimático (ELISA) no diagnóstico da neurocisticercose. Sâo Paulo, 1983. (Tese de doutorado - Instituto de Ciências Biomédicas da Universidade de Sāo Paulor.

4. GALEN, R. S. \& GAMBINO, S. R. - Beyond normality: the predictive value and efficiency of medical diagnosis. New York, John Wiley, 1975.

5. GONZALES-LUARCA, E. - Situaçāo atual do complexo teniase humana-cisticercose nas Américas. Comun. cient. Fac. Med. Vet. Zootec. Univ. S. Paulo, 8: 223-226, 1984.

6. HOSHINO SHIMIZU, S.: CAMARGO, M. E. \& NAGAS SE, T. K. - A stable polysaccharide-haemagglutination reagent for the diagnosis of acute or recent Trypanosoma cruzi infection. Rev. Inst. Med. trop. S. Paulo, 20: 208 212, 1978.

7. MAHAJAN, R. C. CHITKARA, N. L. \& CHOPRA, J. S - Evaluation of cysticercous and adult worm antigens in serodiagnosis of cysticercosis. Indian J. med. Res., 62: $1310-1313,1974$

8. MARTINEZ-CAIRO, S; RUIZ-MACIAS, C.: LOPEZ-RO MAN, M. \& MATEOS-GOMEZ, H. - Usefulness of concentrated CSF haemagglutination technic for the diagnosis of cerebral cysticercosis. Arch. invest. med. (Méx.), 11: $347-359,1980$

9. MILLER, B. L, STAUGAITIS, S. M.; TOURTELLOTTE, W. W.: SHAPSHAK, P.: GOLDBERG, M. HEINER, D. \& WEIL, M. - Intra-blood-brain barrier IgG synthesis in cerebral cysticercosis. Arch. Neurol. (Chic.), 42: 782-784, 1985

10. NASCIMENTO, E. \& MAYRINK, W - Avaliaçăo de antí genos de Cysticercus cellulosae no imunodiagnóstico da cisticercose humana pela hemaglutinação indireta. Rev. Inst. Med. trop. S. Paulo, 26: 289-294, 1984.

11. OBERHAUSER, E. \& WEINSTEIN, V. - Estudio comparativo de líquido cefalorraquídeo y sangre en lúes y cysticercosis cerebral. Acta neurol. 1at.-amer., 14: 74-82, 1968.

12. POWELL, S. J.; PROCTOR, E. M.; WILMOT, A. J. \& BAR NETT, A. M. - Neurological complications of cysticercosis in Africans: a clinical and serological study. Ann. trop. Med. Parasit., 60: 159-164, 1966.

13. PROCTOR, E. M.; POWELL, S. J. \& ELSDON-DEW, R. - The serological diagnosis of cysticercosis. Ann. trop. Med. Parasit., 60: 146-151, 1966. 
UEDA, M.: CAMARGO,E. D.: VAZ,A.J.; SOUZA.A.M. C.de: BENELLI. R. M. F. \& SILVA. M. V.da - Passive haemagglutination test for human neurocystircercosis immunodiagnosis. I. Standardization and evaluation of the passive haemagglutination test for the detection of anti Cysticercus cellulosae antibodies. Rev. Inst. Med. trop. São Paulo, 30: (1) 51-56. 1988.

14. SCHAN'TS, P. M : SCHANKS, D. \& WILSON. M. - Serological cross-reactions with sera from patients with ecchino coccosis and cysticercosis. Amer. J. trop. Med. Hyg., 29: $609-612,1980$

15. SCHENONE, H : VILLARROEL, F : ROJAS, A \& RAMI REZ, R. - Epidemiology of human cysticercosis in Latin America. in: FLISSER, A. ed. - Cysticercosis: present state of knowledge and perspective. New Y ork. Academic Press. 1982
16. SCOTT, T. A. \& MELVIN, E. H. - Determination of dex tran with antrone. Analyt. Chem., 25: 1656 1661, 1953.

17. SPINA-FRANÇA. A. - Imunobiologia da cisticercose avaliaçào dos conceitos atuais. Arq. Neuro-psiquiat., is Paulo), 27: 125 140, 1969

Recebido para publicaçảo em $29 \cdot 9 \cdot 1987$ 